\title{
THE ROLE OF FARMERS GROUPS IN INCREASING SUSTAINABLE RICE PADDY FARMING BUSINESS IN LUBUK BAYAS VILLAGE OF PERBAUNGAN SUBDISTRICT
}

\author{
Nomi Noviani ${ }^{1}$; Sri Wahyuni ${ }^{2}$; Leni Handayani ${ }^{3}$; Bambang Hermanto ${ }^{4}$ \\ ${ }^{1234} \mathrm{Al}$ Wasliyah Nusantara Muslim University \\ 1nominoviani@umnaw.ac.id
}

\begin{abstract}
Farmer groups as a forum for organization and collaboration between members have a very important role in the life of the farming community, because all activities and problems in farming are carried out by groups simultaneously. With the existence of farmer groups, farmers can jointly solve problems which include the fulfillment of agricultural production facilities, technical production and marketing of products. Seeing this potential, farmer groups need to be fostered and empowered further in order to develop optimally. In increasing rice production, it is necessary to preserve the production environment, one of which is through the use of organic fertilizers. Various forms and materials of organic fertilizer can be applied depending on the availability at the farm location. In an effort to improve sustainable farming. The things that are applied are increasing productivity in farming activities and the use of superior seeds, the use of fertilizers, pesticides and the application of cooperation for the manufacture of fertilizers so that group members do not need to buy fertilizer. The existence of institutions/KUD in a village is very helpful for farming communities because these institutions can also take capital loans for farmers so that farmers are able to provide good production facilities, which so far farmers have only relied on outside capital, which is not certain whether they can afford it. continue to cooperate with farmer groups.
\end{abstract}

Keywords: The Role of Farmer Groups, Farming, Sustainable

\section{A. Introduction}

Institutions developed in the context of realizing farmer self-reliance are farmer groups which are working groups that are expected to function as disseminators of innovation to farmers. Farmer groups are a common forum for farmers in order to manage farming as well as all farming issues, a forum for the learning process for farmers in carrying out farming activities optimally and in increasing production. (Fajrin, 2012) 
Hasibuan in Mosher (2016: 9) The farmer group can indirectly be used as one of the efforts to increase the productivity of farmers through the management of agricultural businesses simultaneously. Peasant groups are also used as a medium of learning organization and cooperation between farmers. With the existence of farmers groups, farmers can jointly solve problems that include the fulfillment of agricultural production facilities, technical production and marketing of produce. Farmers groups as a forum for organization and cooperation between members have a very important role in the life of the peasant community, because all activities and problems in trying to farm are carried out by the group simultaneously. Seeing this potential, the farmer group needs to be built and the role of the farmer group in agriculture becomes very important in the life of the farming community, because all activities and problems in trying to farm are carried out by the group simultaneously. With the existence of farmers groups, farmers can jointly solve problems that include the fulfillment of agricultural production facilities, technical production and marketing of produce. Seeing this potential, the farmer group needs to be built and further empowered in order to develop optimally Usman in Soejono (2013: 7)

To go towards sustainable agriculture, the focus of farmers is not only to increase production, but also how to keep the environment sustainable, especially in keeping forest areas from flooding that has an impact on the decline in rice paddy production. (Pirngadi, 2019)

In an effort to increase rice paddy farming in a sustainable manner, efforts are needed that lead to the efficiency of farming by utilizing local resources. In increasing rice production, environmental conservation needs to be done.

The low willingness of rice paddy farmers in paying for upstream environmental improvement services sub-watershed Sarap which has now led to drought in the dry season and floods in the rainy season that resulted in losses received by farmers as a result of drought and flooding that occurred in the rainy season. (Pirngadi, 2019)

In addition to environmental improvements to produce sustainable agriculture in order to produce maximum production, one of them is through the utilization of organic fertilizers. Various forms and materials of organic fertilizer can be given depending on availability at the farm site, so far in some areas there are still many local resources that can be used as organic fertilizers, but have not been optimally utilized, including cow and sheep dung, even in some livestock centers, the dirt becomes a source of agricultural environmental pollution continued in the long term (sustainable agriculture) with low 
chemical input. (low chemical input) known as LEISA is a form of agricultural production that uses locally available resources optimally and minimizes the use of outside inputs. The use of organic matter is an action to improve the environment of growing plants that among others can increase the efficiency of fertilizers.

Lubuk bayas village located in the district of serdang bedagai regency. The area of organic rice fields amounted to 10 ha and productivity was 50 tons / growing season. Organic farmers form farming groups to be able to cooperate in organic rice paddy farming business. and get information for the development of organic farming in lubuk bayas village. There are two groups of farmers who have implemented sustainable agriculture in lubuk bayas village with the existence of a group of farmers sustainable agricultural goals can be applied together between farmers.

\section{B. Method}

The data analysis method used in the study is qualitative descriptive, by describing the level of role of the farmer group measured using 5 indicators obtained from the level of ability of the farmer group for the formation of the farmer group. The level of ability of the group is measured by 5 benchmarks / abilities, namely:

1. Farmer groups are able to provide information

2. Farmer groups are able to provide production facilities and facilities

3. Farmer groups are able to plan activities

4. Farmer groups are able to apply five farming technologies

5. Farmer groups are able to cooperate with KUD . institutions

\section{Results and Discussion}

\section{The Role of Farmer Groups in Increasing Sustainable Rice Field Farming}

The role of farming groups in increasing the production of vehicles for farmers to exchange information for their increased production and help each other in agricultural activities. The role of farmers' groups is very important in increasing sustainable rice paddy farming by applying appropriate technology and breakthrough technologies that are environmentally friendly.

\section{a. The Role of Farmer Groups in Disseminating Information i}

To find out the role of farmer groups in disseminating information that all members of farmer groups in disseminating information is classified as high, because it can be seen from all members of farmer groups that play an active role in disseminating 
information while respondents are members of farmer groups who sometimes convey information to group members. Based on this, the role of farmer groups in disseminating information in Lubuk Bayas Village is in the high category because members of farmer groups are actively fighting in conveying information about new things in agriculture, such as the issuance of new seeds, pest and disease drugs, and others.

\section{b. The Role of Farmer Groups in Providing Production Facilities and Facilities}

The role of peasant groups in participating in providing facilities and means of production. The peasant group and indirectly show the cohesiveness of a group itself. The more complete and facilities and production facilities owned by the farmer group, the more likely it is that the farmer group can carry out activities in increasing the production of members of the peasant group itself well.

In the research area, farmers groups are very participating in the provision of facilities and production facilities with the manufacture of organic fertilizers and pesticides, in order to meet organic agricultural saprodi in lubuk bayas village, so they do not buy out of the area anymore because it is available in lubuk bayas village.

\section{c. The Role of Farmer Groups in Activity Planning}

Planning the activities of farmers groups in a rice farming business management is needed to know, organize and determine what activities, how, when and where activities will be carried out based on mutual agreement. Activities carried out by farming groups in Lubuk Bayas Village such as planning the schedule of down rice fields, planning seed scattering time, planting time, fertilizer procurement, pest handling harvest time, and service work to clean irrigation canals and fence the outskirts of rice fields planned by the farmer group before planting. The farmer group requires planning before going down the rice fields because so that members of the farming group can issue their opinions. Planning activities are always carried out before making their farming efforts to plan everything that may at any time be obstacles in trying to farm, such as irrigation canals that may be damaged due to which water for their rice will lack water and others.

In the village of Lubuk bayas the members of the farming group are very excited about the implementation of sustainable rice paddy farming business, from group fertilizer making to be able to advance sustainable and environmentally friendly agriculture that is their desire, but the membership is not too much, then many farmers from other farming groups outside the village who learn to be able to try organic farming, Although changing conventional to organic takes a long time, but public awareness for 
the application of sustainable agriculture in the district has begun to become more widespread.

\section{d. The Role of Farmer Groups in the Application of Post-harvest Technology}

Farming groups use technology. Panca farming business is one of the technologies for increasing agricultural production consisting of five types of technology packages that include: the use of superior seeds, balanced fertilization, disease pest control, irrigation and soil processing. Dedasa lubuk bayas has done modern post-harvest technology that is assisted by agricultural extensionists who have been certified for the application of organic agriculture, so that the use of seeds, fertilizers, organic pesticides in lubuk bayas villages can increase sustainable rice paddy farming business.

\section{e. The Role of Farmer Groups in Collaborating with KUD Lembaga Institutions}

In the village of Lubuk Bayas there is no government institution or KUD (Village Unit Cooperative), farmers groups cooperate with outside communities that provide capital to market organic rice, then the model is used to pay for rice paddy production, this way is done because they do not accept intermediary traders, the production proceeds are directly sold to the chairman of the marketing group so that members of the farming group get a higher selling price.

\section{Farmer Groups Inhibiting Factors}

The inhibiting factors for increasing lowland rice farming in Lubuk Bayas Village, Perbaungan District are as follows:

a. Lack of institutions/KUD

Lack of institutions / KUD in lubuk bayas village so that farmers have difficulty getting fertilizer, seeds and others. The existence of institutions / KUD in a village is very helpful to the farming community because from the institution can also take out capital loans for farmers so that farmers are able to provide good production facilities, which so far farmers only rely on outside capital that cannot be ascertained whether they can continue to cooperate with farmers groups.

b. Lack of support from local government

Farmers groups have several times submitted capital proposals because lubuk bayas villages have the potential of sustainable rice paddy farming but the government is less responsive to the proposals of farmers groups. 


\section{Conclusion}

Of the five indicators of the role of farmers groups in lubuk bayas villages, the members have applied five indicators well, for the improvement of sustainable farming, the things that are applied are increased productivity in agricultural activities and the use of superior seeds, the use of fertilizers, pesticides and the application of cooperation for fertilizer manufacturing so that group members do not need to buy fertilizer.

Lack of institutions / KUD in lubuk bayas village. The existence of institutions / KUD in a village is very helpful for the farming community because from these institutions can also take out capital loans for farmers so that farmers are able to provide good production facilities, which so far farmers only rely on outside capital that cannot be ascertained whether they can continue to cooperate with farmers groups, lack of support from local governments. Farmers groups have several times submitted capital proposals because lubuk bayas villages have the potential of sustainable rice paddy farming but the government is less responsive to the proposals of farmers groups.

\section{Bibliography}

Fajrin, R. (2012). Kelembagaan yang Dikembangkan dalam Rangka Mewujudkan Swadaya Petani. Malang: Universitas Brawijaya.

Halimah, S., \& Subari, S. (2020). Peran Penyuluh Pertanian Lapang Dalam Pengembangan Kelompok Tani Padi Sawah (Studi Kasus Kelompok Tani Padi Sawah di Desa Gili Barat Kecamatan Kamal Kabupaten Bangkalan) . Jurnal Agriscience, 1(1), 103-114. doi:10.21107/agriscience.v1i1.7794

Latifarruhma, E., Dalmiyatun, T., \& Mardiningsih, D. (2019). Peran Kelompok Tani Akasia Terhadap Keberdayaan Petani Padi Sawah di Desa Cabean Kecamatan Demak Kabupaten Demak Jawa Tengah. SOCA: Jurnal Sosial Ekonomi Pertanian, 13(3), 317-330. doi:10.24843/SOCA.2019.v13.i03.p03

Pirngadi, R. S. (2019). Faktor-Faktor Yang Mempengaruhi Kesediaan Petani Dalam Membayar Jasa Lingkungan Air Padi Sawah. AGRIFO: Jurnal Agribisni Universitas Malikussaleh, 4(1), 51-57. doi:10.29103/ag.v4i1.1541

Sujitno, E., Kurnia, \& Fahmi, T. (2015). Penggunaan Berbagai Pupuk Organik Pada Tanaman Padi di Lahan Sawah Irigasi. Prosiding Seminar Nasional Pertanian Organik. Bogor: Balitro: Balai Penelitian Tanaman Rempah dan Obat. 